\title{
The Effect of IT knowledge and IT Training on the IT Utilization among External Auditors: Evidence from Yemen
}

\author{
Ali Ali Al-Ansi ${ }^{1}$, Noor Azizi Bin Ismail ${ }^{1} \&$ Abdullah Kaid Al-Swidi ${ }^{1}$ \\ ${ }^{1}$ Othman Yeop Abdullah Graduate School of Business, University Utara Malaysia, Sintok, Malaysia \\ Correspondence: Abdullah Kaid Al-Swidi, Othman Yeop Abdullah Graduate School of Business, University \\ Utara Malaysia, Sintok, Malaysia. Tel: 60-12-466-2754. E-mail: swidi@uum.edu.my
}

Received: May 5, 2013 Accepted: June 10, 2013 Online Published: August 1, 2013

doi:10.5539/ass.v9n10p307

URL: http://dx.doi.org/10.5539/ass.v9n10p307

\begin{abstract}
This study aimed to investigate the level of IT utilization and the factors that influence the IT utilization among the audit practitioners in Yemen. The proposed model investigates the impact of IT knowledge, IT training and firm category on the IT utilization. The researchers use a survey questionnaire, the data were collected from 197 external auditors representing Big-4 and non-Big-4 firms operating in Yemen. The Partial Least Squares (PLS) Structural Equations Modeling Approach was employed to analyze the data and test the proposed model. The results showed that IT knowledge and IT training significantly contributed to IT utilization among the external auditors. The originality of this paper comes from the way it contributes towards understanding the joint effect of IT knowledge and training in understanding the IT utilization. In addition, it enhances the current understanding of the moderating effect of the firm category, Big 4 and Non-Big 4, on the relationship between the IT Training and the IT utilization among external auditors.
\end{abstract}

Keywords: external auditors, information technology, IT utilization, IT knowledge, IT training, firm category, Yemen

\section{Introduction}

The use of information technology (IT) is becoming increasingly popular in business. In the last century, the computer was one of the most governing technological advances. Information technologies have had a strong effect on many areas of people activities, such as business, science, engineering, and medicine. The advent of IT has changed the way many organizations used to follow to conduct their businesses. IT systems can carry out a lot of duties and management is recurrently found new ways to utilize the computer and the supporting systems to support operational efficiency and to help in future judgment and decision making. Since many businesses use computers, external auditors are having problems adjusting to the rapidly changing technology aspect (Ismail \& Abidin, 2009; Yang \& Guan, 2004).

Curtis and Payne (2008) argued that with an environment of the audit profession improving audit performance is mainly important which is one of the responsibilities and workload for external auditors. In other words, one of the main responsibilities of the auditors is to detect the frauds as required by Statement on Audit Standards (SAS) No. 99 and now internal control attestation is required under Section 404 of the Sarbanes-Oxley Act and Public Company Accounting Oversight Board (PCAOB) Audit Standard No. 5.

Officially, the standards might as well reflect issuing rules to practitioners concerning the utilization of IT in these areas. Several professional bodies, such as the American Institute of Certified Public Accountants (AICPA), Information Systems Audit and Control Association (ISACA), and International Federation of Accountants (IFAC), have issued standards in this field and encouraged auditors and audit firms to adopt IT specialists when they needed (Janvrin et al., 2008; Yang et al., 2004).

Competence in IT is very important for professional accountants because of its widespread use in the business world and its ability to enhance the effectiveness and efficiency of the auditing profession (IFAC, 2001; Ismail \& Abidin, 2009). Even though auditors' IT knowledge is requested by the professional standards, very few available research investigating the utilization of IT and the factors that influence the utilization (Ismail \& Abidin, 2009; Janvrin, Bierstaker, \& Lowe, 2008) especially those in the developing economies like Yemen.

Moreover, Janvrin et al. (2008) pointed out to this gap in their result where they found auditors indicated that IT 
was important for more than a few applications such as internal control evaluation, risk assessment, audit planning, client relationship, fraud review, and client acceptance even though not utilized extensively, thus suggesting several potential applications where audit firms could regard as important for their IT. They also maintained that IT utilize might impact audit judgment in a straight line and eventually audit performance.

In the context of Yemen, the auditors are not using sophisticated information technology during their audit job (Al-Kharbi, 2010). Conversely, it can be said that the poor utilization of information technology systems contribute significantly to the poor performance of external auditors. As a matter of fact, as argued by Al-Kharbi (2010), the audit profession in Yemen have been facing many difficulties pertaining to the lack of research in the IT audit field, which should highlight the impact of IT on the audit and providing the necessary frameworks, tools and techniques. If auditing firms are not updated in terms of the usage of information systems, they cannot cope with the many challenges being imposed by the technology-driven business environment. In support of that, Alsnafi (2010) revealed that those interested in the audit profession clearly realize the gap between the actual practice of auditors and the requirements regarding the IT-related improvement of the audit profession.

In addition to that, Aldois (2010) pointed out that the external auditors must keep up with the changes that have been occurring in the Republic of Yemen in the IT environment that have changed all the traditional business processes monitoring and control. He also emphasized that external auditors must change the conventional methods and switch to the modern methods using information technology to insure the validity and credibility of data and information extracted from the electronic accounting systems ultimately. If the auditing practitioners are not updating their working methods, they will be isolated and loss the ability to audit the companies with automated systems.

In fact, auditors with limited IT knowledge, IT training, and IT utilization will lack the capabilities to audit typical clients with complex computer systems. It was stated by the head of the training center in the Central Organization for Control and Auditing (2007), that the lack of IT-related knowledge and training among the auditors is usually the main reason why several auditors apologized to undertake the auditing job for clients with complex computer systems in Yemen.

Although there has been prior research regarding the adoption of IT, very little research has concentrated on its use for external auditing. Existing research either concentrations on internal auditing, which has dissimilar purposes to external auditing. This paper aims to fill this gap in the research literature by investigates the level of IT utilization and to what extent is affected by the IT knowledge and IT training in the context of auditing jobs in Yemen.

\section{Literature Review}

\subsection{Information Technology: Definition and Categories}

There are many definitions of IT. This study adopted the International Federation of Accountants Education Committee's (IFAC) (2001) definition because it is comprehensive and sensational. IFAC (2001) defines IT as:

"IT is the hardware and software products, information system operations and management processes, IT controls frameworks, and the human resources and skills required to develop, use and control these products and processes to generate the required information."

This study used the list of IT suggested by IFAC as presented in Table 1. Following Ismail and Abidin (2009) and Greenstein and Mckee (2008), the sixteen technologies are divided into five categories, namely the general office automation, accounting firm office automation, audit automation, e-commerce technologies, and system design and implementation. 
Table 1. Information technology definitions

\begin{tabular}{|c|c|c|c|}
\hline & Category/Technology & Source & Definitions \\
\hline \multicolumn{4}{|c|}{ General Office Automation: } \\
\hline 1. & Word Processing & $\begin{array}{l}\text { IFAC } \\
11\end{array}$ & $\begin{array}{l}\text { "Computer program that facilitates entry and preparation of } \\
\text { documents such as letters or reports." }\end{array}$ \\
\hline 2. & Electronic Spreadsheets & $\begin{array}{l}\text { IFAC } \\
11\end{array}$ & $\begin{array}{l}\text { "Software which allows the auditor to enter either alphanumeric or } \\
\text { numeric data and manipulate it either via standard functions or auditor } \\
\text { programmed functions." }\end{array}$ \\
\hline 3. & E-Mail & $\begin{array}{l}\text { IFAC } \\
11\end{array}$ & "Exchange of mail messages via Intranets and/or the Internet." \\
\hline 4. & Electronic Presentations & $\begin{array}{l}\text { IFAC } \\
11\end{array}$ & $\begin{array}{l}\text { oftware that facilitates the or } \\
\text { /or images to communicate }\end{array}$ \\
\hline
\end{tabular}

\section{Accounting Firm Office Automation:}

5. Small Business

Accounting Software

6. Tax Return Preparation

Software

7. Time Management \&

Billing Systems

\section{Audit Automation:}

8. Electronic Working Papers

9. Generalized Audit

Software

10. Expert Systems

\section{E-Commerce Technologies:}

11. Electronic Data

Interchange (EDI)

-Traditional

12. Internal Network

Configurations
IFAC

11

IFAC

11

IFAC

11

IFAC

11

IFAC

11

IFAC

11

IFAC

11

IFAC

11 and/or images to communicate concepts."

"Accounting software package used to record transactions, maintain general and subsidiary ledgers, and generate financial statements."

"Software, perhaps incorporating expert knowledge, which assists the accountant/auditor in identifying relevant information, capturing and recording it in a manner that can be filed with tax authorities."

"A computer program which assists in capturing, managing, billing, and reporting time spent on professional activities."

"Software which generates a trial balance, lead schedules, and other schedules useful for the recording of evidence in an audit or assurance engagement."

"A computer program which helps the auditor access client computer data files, extract relevant data, and perform some audit function such as addition or comparison."

"Computer software that provides relevant information and/or decision models to assist a human in making a decision or accomplishing some task."

Systems Design and Implementation:

13. Test Data IFAC

11

14. Database Search \&

Retrieval

15. Database Design \& Installation

16. Computer Aided Systems Engineering (CASE) Tools
IFAC

11

IFAC

11

IFAC

11

“Transfer of data or payments electronically between computers using software that may, or may not, require human intervention to affect the transfer."

"Linkage of individuals and data through hardware and software systems that permit the exchange of various types of data."

"A set of transactions processed by the auditor to test the programmed or procedural operations of a computer application."

"Software that uses relational structures between data files and facilitates varying data retrieval and use."

"Software that permits the creation and use of relational structures between data files."

"Integrated package of computer tools that automate important aspects of the software development process to increase software development effectiveness in terms of productivity of systems development and quality of developed systems."

Source: IFAC (2001) [Adapted from Ismail and Abidin, (2009); Greenstein and Mckee, (2008)]

\subsection{Utilization of IT}

Information technologies have been significantly impacted the performance of the external auditors for few decades. There is a strong need to understand the phenomenon better because many different companies increase implementation of group support technologies. To increase the efficiency in the organization, they have to use 
the technology support for cooperative work. Janvrin et al. (2008) found that the use of audit applications and perceived importance vary significantly. As a result, it is important to examine the use of technologies in better depth (Seetharaman, 2006). A few researchers have focused on situations where utilization can regularly be presumed and have argued that the performance is the outcome of appropriate task-technology fit (Goodhue, 1995; Thompson, 1995).

Janvrin et al. (2008) showed that the efficient utilization of tool and perceived importance also vary significantly. Email, cell phones, and remote network access were the uppermost level of utilization ratings whereas auditors assigned lower level of utilization means to instant messaging and extensible business reporting language. Likewise, auditors assigned uppermost importance means to remote network access, cell phones, and email. Bierstaker, Burnaby and Thibodeau (2001) indicated that technologies are already having the most important impact on audit planning. For instance, computers are used to generate customer specific internal control templates to assist the strengths and weaknesses in a system.

Audit practitioners need to implant technology during the audit process, similar to their clients in order to be effective (Ismail \& Abidin, 2009; Winograd, Gerson \& Berlin, 2000). In fact, it has been suggested that the audit profession should respond rapidly to the technological advancements to enhance the auditors' performance (Solomon \& Trotman, 2003)

According to the literature, there has been six ways through which the IT have significantly impacted the auditors: (1) Firms are progressively using technology to smooth the progress of documentation, (2) Big firms are increasing computerized decision assists to help them in their work, (3) Small firms motivate to adopt IT, (4) IT influences the performance and attitudes of auditors and the construction and procedures of the firm. For example, the use of IT could decrease the auditors' time expend accomplishment responsibilities and enhance the quality of audit performance by organizing decision of audit procedures, (5) IT increase audit performance and quality via audit automation, reducing certain procedures in auditing, and improving knowledge, information and capabilities of auditors, and (6) Numerous latest standards organize the increased role for IT in auditing (Janvrin et al., 2008).

Suitable utilization of IT effects produces innovations of organizations and restructured commercial processes, and advantageous competitive dynamics support better performance because of these innovations. Automation of audit jobs and utilize of particular audit software have replaced IT for employment and changed the construction of audit teams (Banker, Chang \& Kao, 2002; Gogan, Applegate \& Nolan, 1995).

The owner and executives embrace important roles in the decision making should utilize information technology in their companies. Besides, their involvement in the process of technology adoption holds important factors in improving the intensity of the use of IT (Suhendra, Hermana \& Sugiharto, 2009).

Managers can justify the investment in information technology if they understood the possible benefits causing from this investment. Even though the perception in overall that IT investments by audit firms might increase firms' efficiency (Banker et al., 2002; Lee \& Arentzoff, 1991), the influence of IT on performance of audit firm is not in a straight line detectable. Audit firms required to recognize in what way the technologies can change their labor and whether such change will eventually cause output achievement (Banker et al., 2002).

\subsection{IT Knowledge}

The requirements of IT knowledge for external auditors are greater than accountants subsequently auditors characteristically work for a widespread variation of clients with various information systems (Greenstein \& McKee, 2008). Knowledge-sharing application and audit software are two very important elements of the success IT implementation initiative in the auditing profession (Banker et al., 2002; Gogan et al. 1995). In essence, it is very important to employ the advanced IT systems to share skills and information bases across diverse sections of the organization that has assisted audit firms to influence their employees more successfully.

Merhout and Buchman (2007) indicated that to understand the technologies used in the business environment, auditors must have an IT knowledge and technological skills. To get well with the technological advancements, Auditors have to have the ability to update their technological knowledge in order for them to utilize the AIS to produce a better auditing performance (POB, 2000; Kinney, 2001; AICPA, 2002).

Greenstein and McKee (2008) asserted that the external auditors know how to gain IT benefits by recognizing important technologies and implementation self-valuation to find out how familiar its memberships are about these technologies. They believe that the 35 technologies are diverse sufficient and external auditors have to be knowledgeable with every one of them. They also pointed out that IT knowledge could be more related with efficiency matters more willingly than effectiveness. Therefore, lack of knowledge in certain IT fields could not be as important in the community depending on audit professionals. 
According to the technology acceptance model (TAM), a user's opinion of their knowledge of computer (self-efficacy) enhances their opinions about ease of use of the technologies and usefulness of technologies; this may affect the user's behavioral intentions (Davis, 1989; Greenstein \& McKee, 2008). Based on the prior arguments and other supporting ones, the following hypothesis was proposed to be empirically tested.

\section{$H_{1}$ : IT knowledge has a positive significant effect on the IT utilization among the external auditors.}

\subsection{IT Training}

Training provides and contributes information about performance accomplishment to individuals' self-commitment. In other words, relevant training will help individuals to work effectively in an IT environment (Sulaiman, 2004).

Janvrin, Lowe and Bierstaker (2008) suggested in their results that audit firm management should improve IT training programs to increase the auditors' perception of ease associated with utilizing information technologies specifically Computer-Assisted Audit Techniques (CAATs). In addition, training is an important source of information and experience in order to change self-beliefs (Saks, 1995; Sulaiman, 2004).

Janvrin et al. (2008) suggested several audit applications wherever audit firms may perhaps reflect increasing IT training, or the use of IT. They pointed out that auditors indicated that IT was important for more than a few applications such as internal control evaluation, risk assessment, audit planning, client relationship, fraud review, and client acceptance; even though it is not utilized generally. This advises various potential applications where audit firms might increase the use of different applications and more importantly provide an intensive training about them to be efficiently integrated in the auditing work.

To confirm the importance of training in the IT utilization and subsequently effectiveness of the auditors' work, Compeau and Higgins (1995) stated that some training can enhance the use of IT. Consequently, audit practitioners need to put together on-line audit software as their most important audit tool and collect evidence electronically in order to achieve efficient audit online systems (Bierstaker et al., 2001; Ismail \& Abidin, 2009). Alamodi (2006) mentioned that Yemeni external auditors extremely need training to develop their current IT-related skills to be able to audit the financial statements of e-commerce transactions as efficient as required. Curtis, Jenkins, Bedard, and Deis (2009) emphasized that auditor training with IT which is available to utilize is a crucial factor to influence his or her performance. They suggested that the more IT-related training offered to the auditors, the more effective and efficient work they can produce.

To examine empirically the effect of IT-related training on the IT utilization, the following hypothesis was introduced

\section{$\mathrm{H}_{2}$ : IT-related training has a positive significant effect on the IT utilization among the external auditors.}

\subsection{Firm Category}

Prior research in information systems has indicated that the availability of resources in the auditing firm are motivated to adopt information technology (Riemenschneider et al. 2003). Big 4 firms have the abundant resources that may qualify them to buy advanced information technologies and utilize IT specialists greater than non-Big 4 firms. Consequently, these resources available to promote and facilitate and improve the audit process, which leads to well audit quality.

Janvrin et al. (2008) pointed out that small audit firms possibly are not able to race with big firms on IT investments, resulting in possible economic obstacles to access as well as audit effectiveness and efficiency issues. Big 4 firms have the financial capabilities to buy and implement more advanced IT and use IT specialists to a better extent than non-Big 4 firms. This may enhance the audit quality of the auditors. They also found that audit IT use and perceived importance vary by firm size and they found in their result that IT audit practices of national firms vary by application as to whether they are more comparable with Big 4 or smaller firms.

Previous studies have also suggested that Big 4 audit firms present higher quality audits and offer greater credibility to clients' financial statements than small audit firms (Lennox, 1999; Palmrose, 1988). In addition, audit firms with more wealth at risk from litigation have more motivation to present higher quality audits (Dye, 1993; Reed, Trombley, \& Dhaliwal, 2000).

In reality, regulators are concerned that small audit firms may not be able to compete with bigger firms in terms of IT investment. This may be because of the differences between the size of the clients serviced by these firm types and their corresponding IT needs (Public Oversight Board [POB], 2000; General Accounting Office [GAO], 2003). It is also expected that the effect of IT-related training on IT utilization will be different in Big 4 companies than non-Big 4 ones. 
The previous arguments and other supporting ones led to the introduction of the following hypotheses

\section{$H_{3}$ : Firm category has an effect on the IT utilization among the external auditors \\ $\mathrm{H}_{4}$ : Firm category moderates the effect of IT training on IT utilization}

\section{Research Methodology}

\subsection{Sampling and Data Collection}

This study used the data collected employing the survey questionnaire research design. The researchers surveyed the respondents through the distributed questionnaire. The respondents of this study were the auditors selected randomly from the list of auditors prepared by the Yemeni Certified Public Accountants Association. Out of 350 Questionnaires distributed, 197 were returned and suitable for the data analysis.

\subsection{Variables and Measurements}

The measure of the variables was adopted from the work of Ismail and Abidin, (2009).

Utilization of IT: measurement of this concept is based on a five-point Likert scale where $1=$ no usage 2 = very little usage; 3 = little usage; 4 = moderate usage; 5 = extensive usage

IT Knowledge: measurement of this concept is based on a five-point Likert scale where $1=$ no knowledge; $2=$ very little knowledge; $3=$ little knowledge; $4=$ moderate knowledge; $5=$ extensive knowledge.

IT Training: measurement of this concept is based on a five-point Likert scale where $1=$ strongly disagree, $2=$ disagree; $3=$ neither agree nor disagree; $4=$ agree; $5=$ strongly agree. Measurement of this concept was adopted from Mirani and King (1988). It also consists of one item where the individuals were asked to indicate their frequency of IT training that they have attended on five Likert-type scale anchored with $1=$ never, $2=$ rarely, $3=$ sometimes, $4=$ often, $5=$ always.

Firm Category: this study uses the category of firm as Big-Four and non Big-Four.

\subsection{Sampling Profile}

The results in Table 2 exhibit the profile of firms' category. As for firms, $74.1 \%$ of the respondents are working with the non-Big 4 while $25.9 \%$ of respondents are working with the Big-Four audit firms. Table 3 indicates that only $21.3 \%$ of the responding firms provide information systems audit and assurance services. The result is similar to previous researches conducted in the developed countries such as McKee (2000), Greenstein and McKee (2004), Greenstein et al. (2005) and Janvrin et al. (2008), and also developing countries such as Ismail and Abidin (2009). See results of this study suggest that information system audit among audit firms in Yemen is still at the minimum level.

Table 4 shows that the majority of respondents (74.4\%) which are auditors (42.3\%) and senior auditor (32.1\%). In terms of age, $44.6 \%$ are between $20-29$, and about $55.4 \%$ of the respondents stated that they are in the category of 30 years old and above. In terms of gender, a total of $180(91.4 \%)$ were males while $17(8.6 \%)$ were females.

Table 2. Firm category

\begin{tabular}{lll}
\hline Category & Frequency & Percent \\
\hline Big-Four & 51 & 25.9 \\
Non Big-Four & 146 & 74.1 \\
Total & $\mathbf{1 9 7}$ & $\mathbf{1 0 0 . 0}$ \\
\hline
\end{tabular}

Table 3. Services provided

\begin{tabular}{ll}
\hline Services & Frequency \\
\hline Audit & 197 \\
Financial Advisory & 112 \\
Tax advisory & 94 \\
Business advisory & 52 \\
Information systems audit and assurance & 42 \\
Others & 29 \\
\hline
\end{tabular}


Table 4. Profile of respondents

\begin{tabular}{lll}
\hline Position & Frequency & Percent \\
\hline Partner & 4 & 2 \\
Audit manager & 19 & 9.7 \\
Senior auditor & 63 & 32.1 \\
Auditor & 83 & 42.3 \\
Audit trainee & 10 & 5.1 \\
Others & 17 & 8.7 \\
Total & 196 & 100 \\
Missing system & 1 & \\
Gender & & \\
Male & 180 & 91.4 \\
Female & 17 & 8.6 \\
Total & 197 & 100 \\
Age range & & \\
$20-29$ & 87 & 44.6 \\
$30-39$ & 79 & 40.5 \\
$40-49$ & 23 & 11.8 \\
50 and above & 6 & 3.1 \\
Total & 195 & 100 \\
Missing system & 2 & \\
\hline
\end{tabular}

\subsection{Data Analysis and Findings}

This study followed the two steps approach suggested by Chin (1998) to examine the structural model containing the IT knowledge, IT training, firm category and IT utilization.

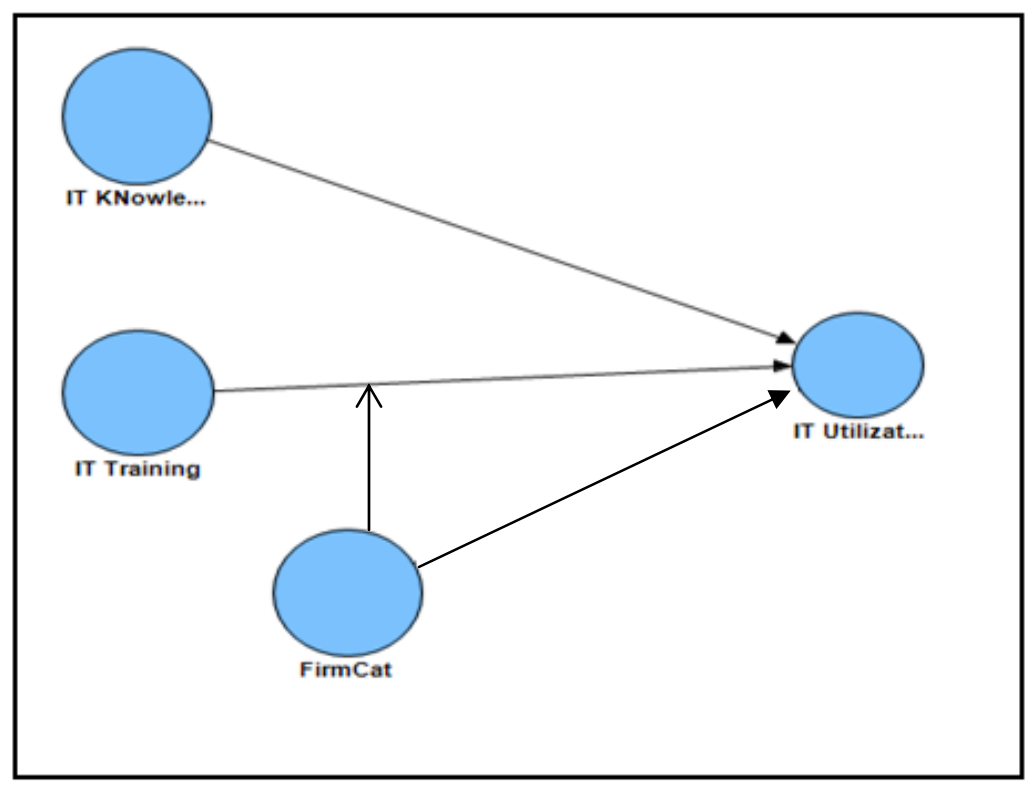

Figure 1. The research model

More specifically, the process was to establish the construct validity and reliability through the measurement analysis before the hypotheses to be tested.

3.4.1 The Measurement Model

The goodness of measurement, outer, model has been examined the content validity and the construct validity as 
detailed in the following.

\section{1) The Content Validity}

The content validity of a construct implies that all the items designed to measure a particular construct should load highly on the construct they were designed to measure. Therefore, the factor loading could be used to assess the content validity as suggested by Hair et al. (2010) and Chin (1998). On the other hand, if some items load on some other constructs higher than their respective construct, these items will be candidates to be deleted. Tables 5 and 6 showed that all the variables significantly loaded on their respective constructs. This, in fact, confirmed the content validity of the measurement model.

Table 5. Cross-loading of the items

\begin{tabular}{|c|c|c|c|}
\hline Item/Construct & IT Knowledge & IT Training & IT Utilization \\
\hline K1 & 0.730 & 0.286 & 0.411 \\
\hline $\mathrm{K} 2$ & 0.830 & 0.328 & 0.497 \\
\hline K3 & 0.703 & 0.173 & 0.386 \\
\hline K4 & 0.699 & 0.185 & 0.288 \\
\hline K5 & 0.729 & 0.215 & 0.341 \\
\hline K6 & 0.686 & 0.155 & 0.416 \\
\hline K7 & 0.526 & 0.180 & 0.366 \\
\hline K8 & 0.693 & 0.349 & 0.569 \\
\hline ITT1 & 0.380 & 0.570 & 0.451 \\
\hline ITT2 & 0.133 & 0.723 & 0.136 \\
\hline ITT3 & 0.131 & 0.724 & 0.145 \\
\hline ITT4 & 0.173 & 0.774 & 0.249 \\
\hline ITT5 & 0.111 & 0.668 & 0.078 \\
\hline ITT6 & 0.179 & 0.762 & 0.168 \\
\hline U1 & 0.301 & 0.231 & 0.686 \\
\hline $\mathrm{U} 2$ & 0.318 & 0.395 & 0.747 \\
\hline U3 & 0.422 & 0.360 & 0.802 \\
\hline $\mathrm{U} 4$ & 0.342 & 0.253 & 0.634 \\
\hline U5 & 0.301 & 0.168 & 0.648 \\
\hline U6 & 0.367 & 0.273 & 0.698 \\
\hline U7 & 0.345 & 0.329 & 0.645 \\
\hline U8 & 0.550 & 0.241 & 0.514 \\
\hline U9 & 0.546 & 0.207 & $\mathbf{0 . 5 3 3}$ \\
\hline U10 & 0.477 & 0.268 & 0.601 \\
\hline U11 & 0.476 & 0.145 & 0.584 \\
\hline U12 & 0.421 & 0.337 & 0.763 \\
\hline U13 & 0.403 & 0.259 & 0.766 \\
\hline U14 & 0.332 & 0.250 & 0.761 \\
\hline U15 & 0.431 & 0.377 & 0.794 \\
\hline U16 & 0.318 & 0.252 & 0.684 \\
\hline
\end{tabular}


Table 6. T value results

\begin{tabular}{|c|c|c|c|c|c|}
\hline Constructs & Items & Loadings & Standard Error & $\mathrm{T}$ value & P value \\
\hline \multirow[t]{8}{*}{ IT Knowledge } & K1 & 0.730 & 0.050 & 14.741 & 0.000 \\
\hline & K2 & 0.830 & 0.030 & 27.993 & 0.000 \\
\hline & K3 & 0.703 & 0.045 & 15.779 & 0.000 \\
\hline & K4 & 0.699 & 0.066 & 10.625 & 0.000 \\
\hline & K5 & 0.729 & 0.061 & 12.048 & 0.000 \\
\hline & K6 & 0.686 & 0.049 & 14.088 & 0.000 \\
\hline & K7 & 0.526 & 0.054 & 9.826 & 0.000 \\
\hline & K8 & 0.693 & 0.040 & 17.332 & 0.000 \\
\hline \multirow[t]{6}{*}{ IT Training } & ITT1 & 0.570 & 0.153 & 3.728 & 0.000 \\
\hline & ITT2 & 0.723 & 0.158 & 4.573 & 0.000 \\
\hline & ITT3 & 0.724 & 0.170 & 4.259 & 0.000 \\
\hline & ITT4 & 0.774 & 0.161 & 4.821 & 0.000 \\
\hline & ITT5 & 0.668 & 0.197 & 3.399 & 0.000 \\
\hline & ITT6 & 0.762 & 0.183 & 4.172 & 0.000 \\
\hline \multirow[t]{16}{*}{ IT Utilization } & U1 & 0.686 & 0.042 & 16.536 & 0.000 \\
\hline & $\mathrm{U} 2$ & 0.747 & 0.032 & 23.173 & 0.000 \\
\hline & U3 & 0.802 & 0.030 & 26.419 & 0.000 \\
\hline & $\mathrm{U} 4$ & 0.634 & 0.051 & 12.378 & 0.000 \\
\hline & U5 & 0.648 & 0.049 & 13.310 & 0.000 \\
\hline & U6 & 0.698 & 0.042 & 16.697 & 0.000 \\
\hline & U7 & 0.645 & 0.047 & 13.709 & 0.000 \\
\hline & U8 & 0.514 & 0.062 & 8.240 & 0.000 \\
\hline & U9 & $\mathbf{0 . 5 3 3}$ & 0.055 & 9.727 & 0.000 \\
\hline & U10 & 0.601 & 0.053 & 11.388 & 0.000 \\
\hline & U11 & 0.584 & 0.058 & 10.127 & 0.000 \\
\hline & U12 & 0.763 & 0.030 & 25.562 & 0.000 \\
\hline & U13 & 0.766 & 0.032 & 24.069 & 0.000 \\
\hline & U14 & 0.761 & 0.034 & 22.512 & 0.000 \\
\hline & U15 & 0.794 & 0.030 & 26.511 & 0.000 \\
\hline & U16 & 0.684 & 0.042 & 16.243 & 0.000 \\
\hline
\end{tabular}

\section{2) The Convergent Validity}

As defined by Bagozzi, Yi and Phillips (1991) and Hair et al. (2010), the convergent validity is the extent to which a set of variables converges in measuring the concept on the construct. The convergent validity can be confirmed, based on the SEM literature, by using the item's reliability, composite reliability and the average variance extracted. That is, the items of each construct are highly loaded and statistically significant in measuring their respective constructs with at least 0.7 factor loadings, the composite reliability of each construct is at least 0.7 and the average variance extracted (AVE) for each construct is at least 0.5 then the convergent validity can be confidently confirmed (Bagozzi, Yi \& Phillips 1991; Hair et al., 2010).

Table 7 shows that the composite reliability values of all the constructs exceeded the recommended value of 0.7 and all the AVE values are more than 0.5. As a result, it can be confirmed that the measurement model has an adequate level of convergent validity. 
Table 7 . The results of convergent validity analysis

\begin{tabular}{|c|c|c|c|c|c|}
\hline Constructs & Items & Loadings & Cronbach's Alpha & Composite Reliability $^{a}$ & $\mathbf{A V E}^{\mathbf{b}}$ \\
\hline \multirow[t]{8}{*}{ IT Knowledge } & K1 & 0.730 & 0.853 & 0.886 & 0.5 \\
\hline & K2 & 0.830 & & & \\
\hline & K3 & 0.703 & & & \\
\hline & K4 & 0.699 & & & \\
\hline & K5 & 0.729 & & & \\
\hline & K6 & 0.686 & & & \\
\hline & K7 & 0.526 & & & \\
\hline & K8 & 0.693 & & & \\
\hline \multirow[t]{6}{*}{ IT Training } & ITT1 & 0.570 & 0.847 & 0.856 & 0.5 \\
\hline & ITT2 & 0.723 & & & \\
\hline & ITT3 & 0.724 & & & \\
\hline & ITT4 & 0.774 & & & \\
\hline & ITT5 & 0.668 & & & \\
\hline & ITT6 & 0.762 & & & \\
\hline \multirow[t]{16}{*}{ IT Utilization } & U1 & 0.686 & 0.923 & 0.933 & 0.5 \\
\hline & $\mathrm{U} 2$ & 0.747 & & & \\
\hline & U3 & 0.802 & & & \\
\hline & $\mathrm{U} 4$ & 0.634 & & & \\
\hline & U5 & 0.648 & & & \\
\hline & U6 & 0.698 & & & \\
\hline & U7 & 0.645 & & & \\
\hline & U8 & 0.514 & & & \\
\hline & U9 & 0.533 & & & \\
\hline & U10 & 0.601 & & & \\
\hline & U11 & 0.584 & & & \\
\hline & $\mathrm{U} 12$ & 0.763 & & & \\
\hline & U13 & 0.766 & & & \\
\hline & U14 & 0.761 & & & \\
\hline & U15 & 0.794 & & & \\
\hline & U16 & 0.684 & & & \\
\hline
\end{tabular}

a: $\mathrm{CR}=(\Sigma \text { factor loading })^{2} /\left\{(\Sigma \text { factor loading })^{2}\right)+\Sigma$ (variance of error $\left.)\right\}$

b: AVE $=\Sigma$ (factor loading $)^{2} /(\Sigma \text { (factor loading })^{2}+\Sigma($ variance of error $\left.)\right\}$

3) The Discriminant Validity

The degree to which a set of items can differentiate a construct from other constructs is called the discriminant validity. That implies that the variance shared among the items belong to each construct should be greater than that shared with other constructs (Compeau et al., 1999). In examining the discriminant validity of the measurement model, the Fornell and Larcker (1981)'s criterion was employed. Table 8 illustrates the correlation matrix in which the diagonal elements are the square root of the average variance extracted of all the latent constructs. The comparison to be made and the discriminant validity can be assumed if the diagonal elements are higher than other off-diagonal elements in their respective rows and columns. In fact, the results in the correlation matrix illustrated in Table 8 ensure that the discriminant validity is confirmed. 
Table 8 . Correlations among constructs and discriminant validity

\begin{tabular}{llll}
\hline Construct & 1 & 2 & 3 \\
\hline (1) IT Knowledge & $\mathbf{0 . 7 0 4}$ & & \\
(2) IT Training & 0.348 & $\mathbf{0 . 7 0 7}$ & \\
(3) IT Utilization & 0.605 & 0.407 & $\mathbf{0 . 6 8 4}$ \\
\hline
\end{tabular}

\subsubsection{Predictive Relevance of the Model}

In the assessment of the model of the study $\mathrm{R}^{2}$ and Cross-Validated redundancy were utilized. To assess the quality of the overall model of the study, $\mathrm{R}^{2}$ which shows the variance in the endogenous variable that is explained by the exogenous variables. Based on the results reported in Table 9 , the $\mathrm{R}^{2}$ showed that $42 \%$ of the Information Technology Utilization was accounted for by the selected variables in the model. As suggested by Cohen (1988), 0.26 substantial, 0.13 moderate and 0.02 weak; the $R^{2}$ here is considered substantial indicating the power of IT training and It knowledge in explaining the IT utilization.

Another criterion to assess the quality of the model was done through the results obtained through the Blindfolding procedure in SmartPLS which was used to generate the cross-validation commonality and cross-validated redundancy. The main principle on which the Blindfolding procedure was designed is to remove some data and then handle them as missing values to be estimated. These parameters are used later to reconstruct the assumed missing data. Based on that, the comparison will be held to assess how close the real from the implied results and the $\mathrm{Q}^{2}$ values will be calculated. Practically, if the estimation of the data points is obtained by the latent variables that predict the block in question, the output is the cross-validated redundancy.

Table 9. Predictive Revelence of the Model

\begin{tabular}{lccc}
\hline Endogenous & R Sqaure & Cross-Validated Redundancy & Cross-Validated Communality \\
\hline IT Utilization & 0.417 & 0.176 & 0.468 \\
\hline
\end{tabular}

Following the suggestion of Fornell and Cha (1994), the model will be said to have the predictive quality if the cross-redundancy value was found to be more than 0 , otherwise the predictive relevance of the model cannot be assumed. The results in Table 9 showed that the obtained cross validated redundancy was found to be 0.176 . This result supports the claim that the model has an adequate prediction quality.

\subsubsection{Goodness of Fit (GoF) of the Model}

Unlike the CBSEM approach; PLS Structural Equation Modeling has only one measure of goodness of fit which was defined to be the global fit measure by Tenenhaus et al. (2005). Mathematically, this measure is the geometric mean of the average variances extracted and the average $\mathrm{R}^{2}$ for the endogenous variables as given in the following formula

$$
\text { Gof }=\sqrt{\left(\overline{\mathrm{R}^{2}} \times \overline{\mathrm{AVE}}\right)}
$$

However, the GoF value of this model was found to be 0.453 . This value is compared to the baseline values suggested by Wetzels et al. (2009) (small $=0.1$, medium $=0.25$, large $=0.36$ ). The results showed that the model goodness of fit measure based on the average variance explained is large which indicate an adequate level of global PLS model validity.

\subsubsection{The Structural Model and Hypothesis Testing}

After the construct validity and construct reliability have been established, the next step was to test the hypotheses of the study by running PLS Algorithm and Bootstrapping Algorithm in SmartPLS 2.0. 


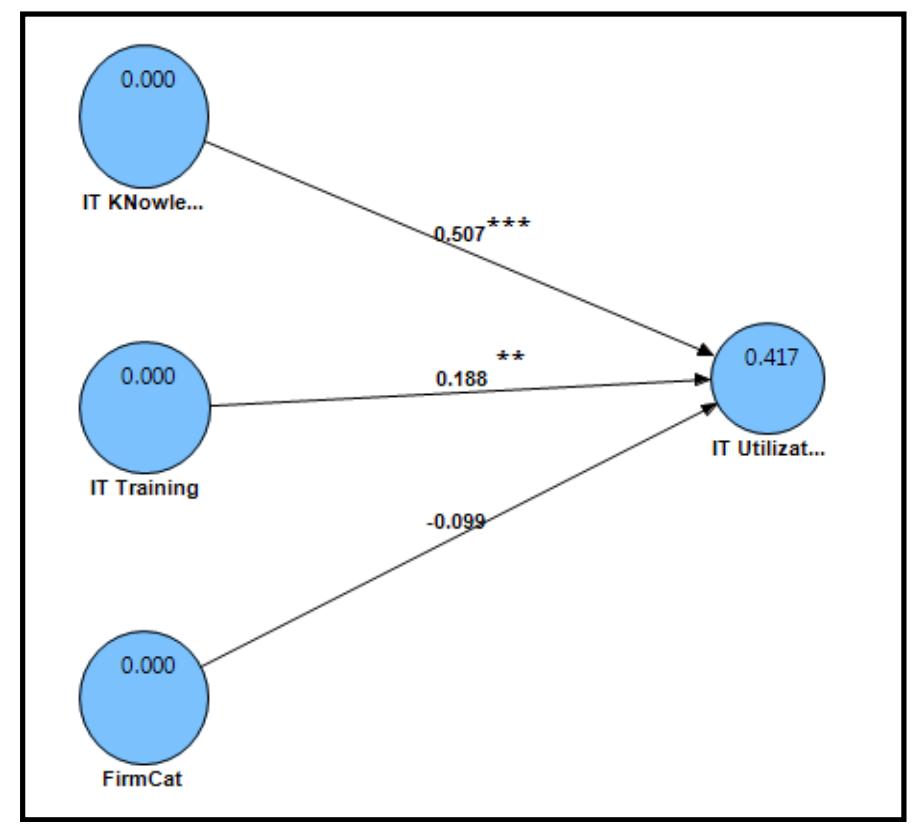

Figure 2. Items loadings and path coefficient

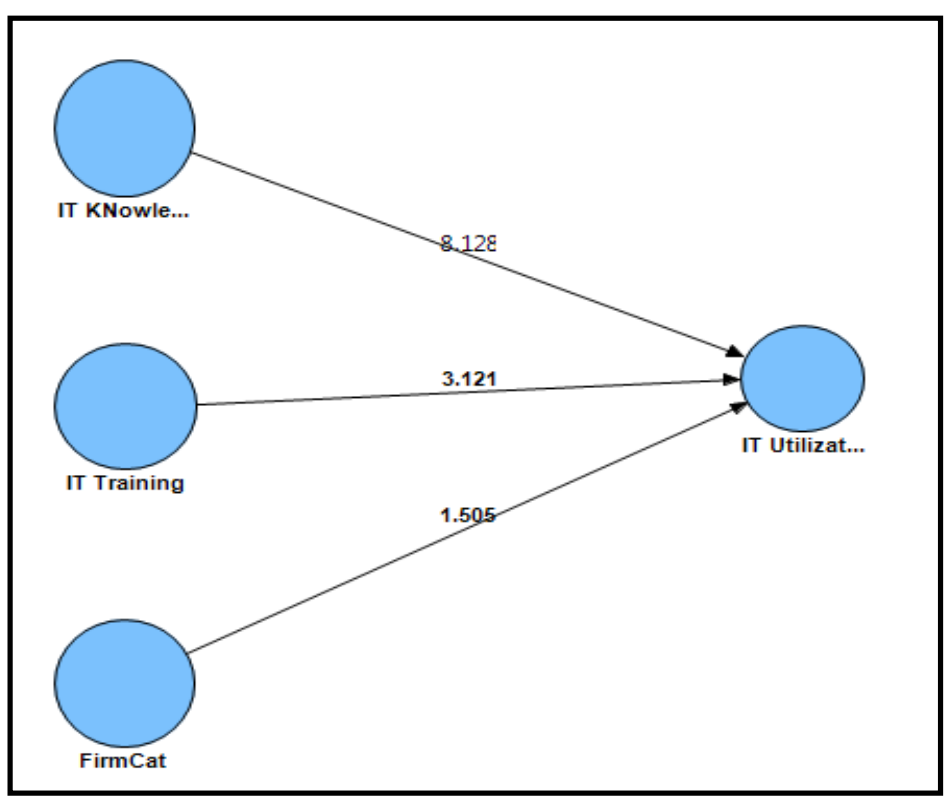

Figure 3. Significance of path coefficient

Table 10. Hypothesis testing result

\begin{tabular}{llllll}
\hline \multicolumn{1}{c}{ Hypothesis } & Path Coefficient & Standard Error & T Value & P Value & Decision \\
\hline Firm Category -> IT Utilization & -0.099 & 0.064 & 1.545 & 0.061 & Not Supported \\
IT Knowledge -> IT Utilization & $0.507^{* * *}$ & 0.061 & 8.246 & 0.000 & Supported \\
IT Training -> IT Utilization & $0.188^{* *}$ & 0.065 & 2.902 & 0.002 & Supported \\
\hline
\end{tabular}

$* * *: \mathrm{p}<0.001 ; * *: \mathrm{p}<0.01$

As indicated in Figures 2, 3 and Table 10, IT Knowledge has a positive significant effect on the IT Utilization at the 0.001 level of significance $(\beta=0.507, t=8.246, p<0.001)$. Similarly, the IT Training has a positive significant effect on the IT Utilization at the 0.01 level of significance $(\beta=0.188, \mathrm{t}=2.902, \mathrm{p}<0.01)$. However, the firm category was not a determinant of the IT Utilization at the 0.05 level of significance. 


\subsubsection{Testing the Moderating Role of Firm Size}

In testing the moderating effect of the firm category on the relationship between the IT Training and the IT utilization, the moderation mechanism in SmartPLS was employed.

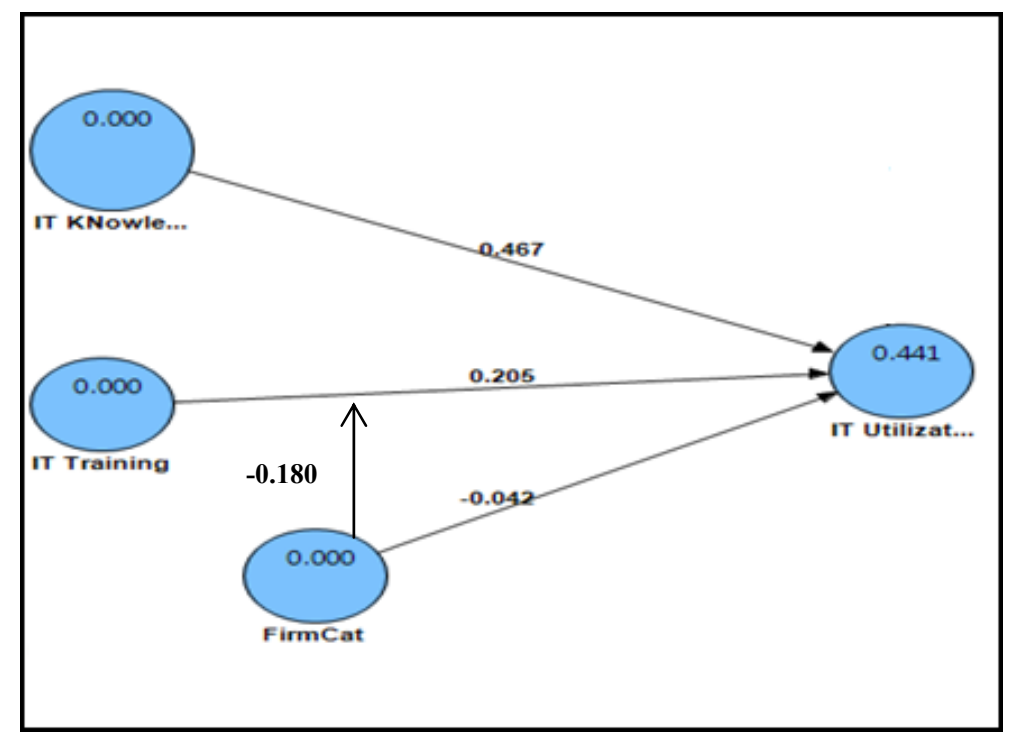

Figure 4. The moderating effect of the Firm Category

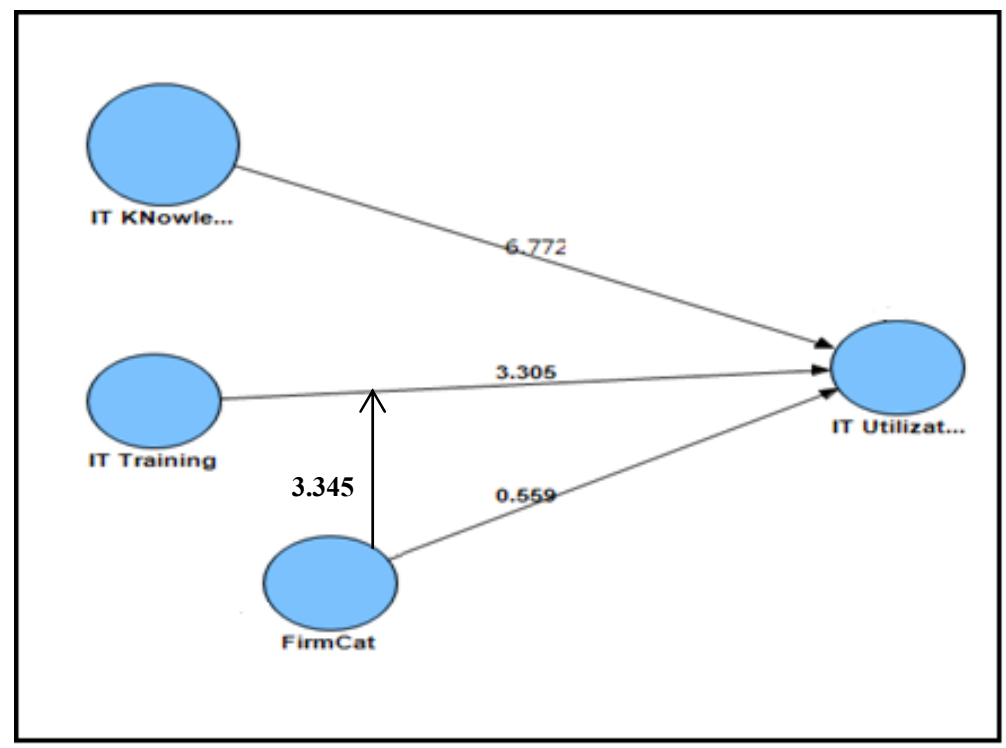

Figure 5. The $\mathrm{T}$ value of the moderated model

The results in the Figures 4 and 5 confirmed the moderating effect of the firm category on the relationship between the IT Training and the IT Utilization as shown in Table 11.

Table 11. Moderating effect results

\begin{tabular}{llllll}
\hline \multicolumn{1}{c}{ Hypothesis } & \multicolumn{1}{c}{$\begin{array}{c}\text { Path } \\
\text { Coefficient }\end{array}$} & $\begin{array}{c}\text { Standard } \\
\text { Error }\end{array}$ & $\begin{array}{c}\text { T } \\
\text { Value }\end{array}$ & $\begin{array}{c}\text { P } \\
\text { Value }\end{array}$ & Decision \\
\hline $\begin{array}{l}\text { Firm Category Moderates the relationship } \\
\text { between IT Training and IT Utilization }\end{array}$ & -0.180 & 0.0547 & 3.345 & 0.000 & Supported \\
\hline
\end{tabular}




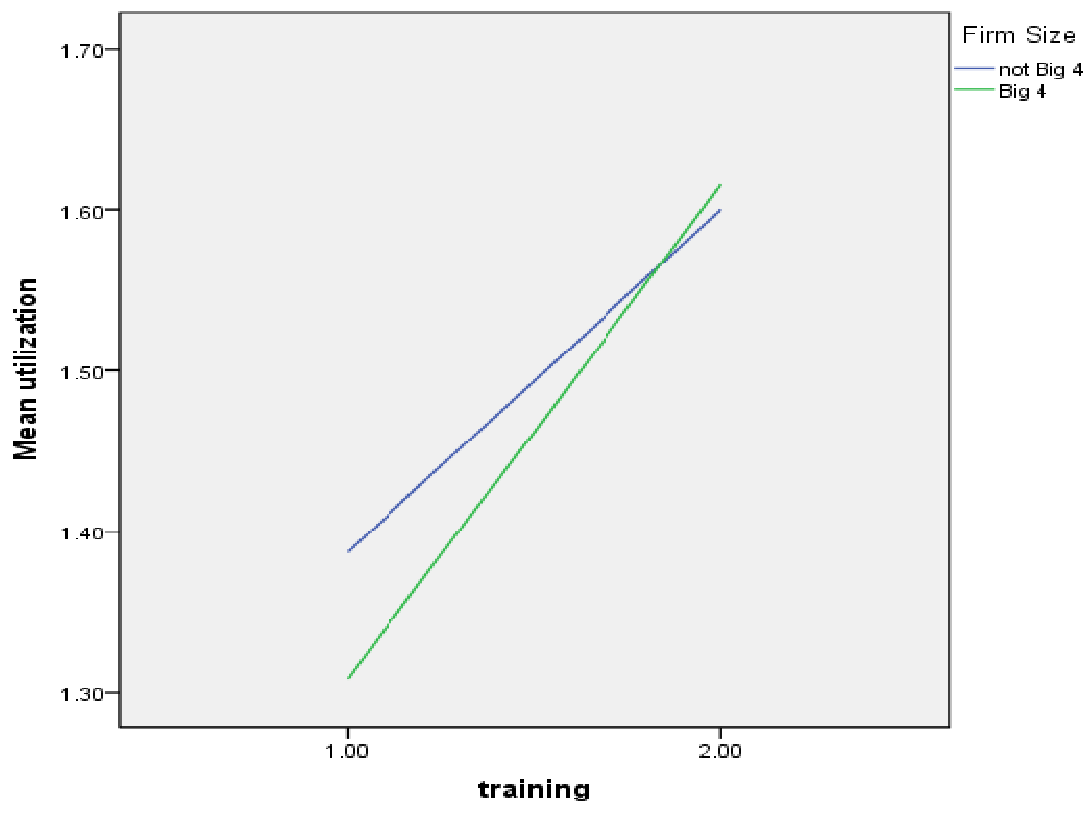

Figure 6. The moderating effect graph

As can be easily seen in the graph in Figure 6, in both big 4 and non-Big 4 companies, the higher the IT training, the more will be the IT Utilization. However, in big 4 companies, the rate of increase in the IT Utilization for any training provided will be faster than that in non-Big 4 companies.

\section{Discussion, Limitations, and Future Research Directions}

This study examined three hypotheses concerning the IT utilization in the specific context of audit work in Yemen. Significantly, this study reaches out the existing literature on utilization of IT in audit work which has received little attention in the literature. In a systematic fashion, testing the three hypotheses against the IT utilization, the positive associations between all independent variables and dependent variable were approved. Firm category appeared to have an insignificant relationship with the dependent variable.

In other words, the results of this study have confirmed the role of IT knowledge and IT training in determining the level of IT utilization among the external auditors. These findings corroborated the previous findings in this regard by confirming the importance of IT knowledge and training on IT utilization among the auditors (Chaveerug \& Ussahawanitchakit, 2009; Janvrin at el., 2008). Logically, if the individuals have no knowledge about the IT and they have not gone through formal training to enhance their capabilities, the utilization of IT systems is expected to be in its lowest level.

This evidence suggests that, auditors' IT knowledge and IT-related training are crucial for firms to increase the IT utilization. In addition, the results imply that information systems audit in Yemen is still at the minimum level. Thus, it suggests that Yemeni Certified Public Accountants Association must introduce a policy which requires auditors to possess a minimum set of IT knowledge and skills to audit firm with complex computer systems.

Interestingly, the moderating effect of the firm category on the IT training and IT utilization showed that in non-Big 4 firms the IT-related training can enhance the IT utilization among the auditors more than that of the Big 4 firms. This is due to the lack of IT-related training programs in non-Big 4 firms and the need of employees to gain a better knowledge to enhance their performance and to be able to audit firms with IT-complex or systemized firms.

Consequently, this study has an important contribution as the results would start the debat, discussion and exploit that will lead to helpful changes in the Yemeni audit job and other developing countries as they move forward in today's technology-intensified environment. This study also has made an important contribution through increasing the current understanding of the moderating effect of the firm category on the relationship between the IT Training and the IT utilization among external auditors.

The results of this study are to be interpreted in the light of its limitations. This study has considered only 16 
technologies that were mostly adopted from previous studies. Consequently, several similarly important technologies possibly will have been unintentionally ignored in the literature and thus are not included in this research. It will be more valuable if the future researchers try to examine the model based on other various technologies that are available in the literature.

In addition to that, this study is also limited by its research design where the respondents are asked to rate their utilization of the IT and this could affect the reality of the practices. Future research could opt to investigate this model based on other research design to validate the findings.

To gain a deeper understanding on the role of information systems on the performance of the auditors, future studies are recommended to put forth some efforts to investigate the fit between the IT importance and the actual utilization of the information technologies. Further studies could also examine the effect of some other influential variables on these relationships. In fact, the reality is very complex and in order for a researcher to have the clear picture, he has to take into account many other variables that might influence the proposed model.

\section{References}

Alamodi, A. (2006). The Impact of Electronic Commerce on the Audit - a Field Study in Yemen. Doctor of Philosophy, Damascus University, Syria.

Aldois, M. (2010). The Extent of Using Information Technology in the Auditing Process and its Impact on External Auditors' Efficiency and Effectiveness in the Republic of Yemen. Doctor of Philosophy, Arab Academy for Banking and Financial Sciences, Jordan.

Al-Kharbi, A. (2010). A Study of The Impact of 'IT' on Audit and The Role of Auditing Organizations to Cope With The Changing Environment of The Accounting Systems with Special Reference to Republic of Yemen. Doctor of Philosophy, Bharati Vidyapeeth Deemed University, India.

Alsnafi, A. (2010, September). Chartered Accountant, Yemeni Association of Certified Public Accountants (Vol.10, pp. 3-4). Sana'a Yemen.

Bagozzi, R. P., Yi, Y., \& Phillips, L. W. (1991). Assessing construct validity in organizational research. Administrative Science Quarterly, 36(3), 421-478. http://dx.doi.org/10.2307/2393203

Banker, P. H., Chang, R. D. H., \& Kao, Y. (2002). Impact of information technology on public accounting firm productivity, Journal of Information Systems, 16(2), 209-222. http://dx.doi.org/10.2308/jis.2002.16.2.209

Bierstaker, J., Burnaby, P., \& Thibodeau, J. (2001). The Impact of Information Technology on the Audit Process: An Assessment of the State of the Art and Implications for the Future. Managerial Auditing Journal, 16(2), 159-164. http://dx.doi.org/10.1108/02686900110385489

Chaveerug, A., \& Ussahawanitchakit, P. (2009). Effective Implementation of Computerized Assisted Auditing of CPAs In Thailand: How Does Influence Audit Performance? International Journal of Business Research, 9(5), 54-75.

Chin, W. W. (1998). The partial least squares approach to structural equation modeling, In G. A. Marcoulides (Ed.), Modern methods for business research (pp. 295-336). Mahwah: Lawrence Erlbaum.

Cohen, J. (1988). Statistical power analysis for the behavioral sciences (2nd ed.). Hillsdale, Lawrence Erlbaum Associates, NJ.

Compeau, D. R., \& Higgins, C. A. (1995). Application of Social Cognitive Theory to Training for Computer Skills. Information Systems Research, 6(2), 118-143. http://dx.doi.org/10.1287/isre.6.2.118

Compeau, D. R., Higgins, C. A., \& Huff, S. (1999). Social Cognitive Theory and individual Reactions to Computing Technology - A Longitudinal-Study. MIS Quarterly, 23(2), 145-158. http://dx.doi.org/10.2307/249749

Curtis, M. B., Jenkins, J. G., Bedard, J. C., \& Deis, D. R. (2009). Auditors' Training and Proficiency in Information Systems: A Research Synthesis. Journal of Information Systems, 23(1), 79-96. http://dx.doi.org/10.2308/jis.2009.23.1.79

Curtis, M. B., \& Payne, E. A. (2008). An examination of contextual factors and individual characteristics affecting technology implementation decisions in auditing. International Journal of Accounting Information Systems, 9(2), 104-121. http://dx.doi.org/10.1016/j.accinf.2007.10.002

Davis, F. (1989). Perceived Usefulness, Perceived Ease of Use, and User Acceptance of Information Technology. MIS Quarterly, 3(3), 319-340. http://dx.doi.org/10.2307/249008 
Dye, R. A. (1993). Auditing standards legal liability and auditor wealth. The Journal of Political Economy, 101(5), 887-914. http://dx.doi.org/10.1086/261908

Fornell C., \& Larcker, D. F. (1981). Evaluating structural equation models with unobservable variables and measurement error. Journal of Market Research, 18(1), 39-50. http://dx.doi.org/10.2307/3151312

Fornell, C., \& Cha, J. (1994). Partial least squares, In R. P. Bagozzi (Ed.), advanced methods of marketing research (pp. 52-78). Cambridge: Blackwell.

Gogan, J., Applegate, L. M., \& Nolan, R. (1995). KPMG Peat Marwick: The shadow partner, Harvard Business School Teaching Note 5-196-066, (Dec. 1), Cambridge, MA: Harvard Business School.

Goodhue, D. L. (1995). Understanding user evaluations of information systems. Management Science, 41(12), 1827-1845. http://dx.doi.org/10.1287/mnsc.41.12.1827

Greenstein-Prosch, M., \& McKee., T. E. (2004). Assurance practitioners' and educators' self-perceived IT knowledge level: An empirical assessment. International Journal of Accounting Information Systems, 5(2), 213-243. http://dx.doi.org/10.1016/j.accinf.2004.04.002

Greenstein-Prosch, M., McKee, T. E., \& Quick, R. (2008). A Comparison of the Information Technology Knowledge of United States and German Auditors. The International Journal of Digital Accounting Research, 8(14), 45-79.

Hair, J. F., Anderson, R. E., Tatham, R. L., \& Black, W. C. (2010). Multivariate Data Analysis (7th ed.). Prentice Hall: USA.

Hillison, W., \& Pacini, C. (2004). Auditor reputation and the insurance hypothesis: The information of content of disclosures of financial distress of a major accounting firm. Journal of Managerial Issues, 16(1), 65-86.

International Federation of Accountants Education Committee (IFAC). (2001). Information technology in the accounting curriculum, IFAC Education Committee Guideline 11. Retrieved from http://www.ifac.org/store/Details.tmpl?SID=303859141967

Ismail, N. A., \& Abidin, A. Z. (2009). Perception towards the importance and knowledge of information technology among auditors in Malaysia. Journal of Accounting and Taxation, 1(4), 61-69.

Janvrin, D., Bierstaker, J., \& Lowe, D. (2008). An examination of audit information technology use and perceived importance. Accounting Horizons, 22(1), 1-21. http://dx.doi.org/10.2308/acch.2008.22.1.1

Janvrin, D., Lowe, D. J., \& Bierstaker, J. (2008). Auditor Acceptance of Computer-Assisted Audit Techniques, Iowa State University, Arizona State University and Villanova University, 4 December.

Lee, J. Y., \& Arentzoff, S. (1991). The productivity factor - Justifying your computer purchase. The National Public Accountant, 22-24.

Lennox, C. (1999). Are large auditors more accurate than small auditors? Accounting and Business Research, 29(3), 217-227. http://dx.doi.org/10.1080/00014788.1999.9729582

Palmrose, Z. V. (1988). An analysis of auditor litigation and audit service quality. The Accounting Review, 63(1), 55-73.

Public Oversight Board (POB). (2000). Panel on Audit Effectiveness, Stamford: Report and Recommendations, Stamford, CT: POB.

Reed, B., Trombley, M., \& Dhaliwal, D. (2000). Demand for audit quality: The case of Laventhol and Horwath's auditees. Journal of Accounting, Auditing and Finance, 15(2), 183-198.

Ridley, G., Young, J., \& Carroll, P. (2004). COBIT and its Utilization: A framework from the literature. Paper presented at the Proceedings of the 37th Hawaii International Conference on System Sciences, 2004, Hawaii. http://dx.doi.org/10.1109/HICSS.2004.1265566

Riemenschneider, C., Harrison, D., \& P. Mykytyn, J. (2003). Understanding IT adoption decisions in small business: Integrating current theories. Information \& Management, 40(4), 269-285. http://dx.doi.org/10.1016/S0378-7206(02)00010-1

Saks, A. M. (1995). Longitudinal field investigation of the moderating and mediating effects of self-efficacy on the relationship between training and newcomer adjustment. Journal of Applied Psychology, 80(2), 211-225. http://dx.doi.org/10.1037/0021-9010.80.2.211

Seetharaman, P. (2006). Collaborative Technology Use: A Multilevel Theory and Empirical Demonstration. 
Indian Institute of Management Calcutta, India.

Solomon, I., \& Trotman, K. (2003). Experimental judgment and decision research in auditing: The first 25 years

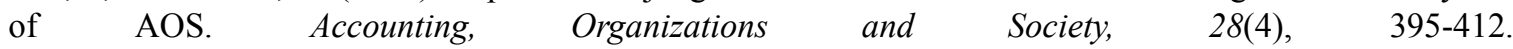
http://dx.doi.org/10.1016/S0361-3682(02)00023-5

Suhendra, E. S., Hermana, B., \& Sugiharto, T. (2009). Behavioral Analysis of Information Technology Acceptance in Indonesia Small Entreprises, Paper presented at the Anadolu International Conference in Economics, 17-19 June, Eskişehir, Turkey.

Sulaiman, W. A. (2004). Organizational Commitment on Information Technology at the State Secretary Office of Perlis, University Utara Malaysia, Kedah.

Tenenhaus, M., Esposito Vinzi, V., Chatelin,Y. M., \& Lauro, C. (2005). PLS path modeling. Computational Statistics \& Data Analysis, 48(1), 159-205. http://dx.doi.org/10.1016/j.csda.2004.03.005

Thompson, R. L. (1995). Task-technology fit and individual performance. MIS Quarterly, 19(2), 213-236. http://dx.doi.org/10.2307/249689

U.S.General Accounting Office (GAO). (2003). Public accounting firms: Mandated study on consolidation and competition. Retrieved from http://www.gao.gov/new.items/d03864.pdf

Wetzels, M., Odekerken-Schröder, G., \& Oppen, C. V. (2009). Using PLS path modeling for assessing hierarchical models: Guidelines and empirical illustration. MIS Quarterly, 33(1), 177-195.

Winograd, B., Gerson, J., \& Berlin, B. (2000). Audit practices of Pricewaterhouse Coopers. AUDITING: A Journal of Practice \& Theory, 19(2), 175-182. http://dx.doi.org/10.2308/aud.2000.19.2.176

Yang, D. C., \& Guan, L. (2004). The evolution of IT auditing and internal control standards in financial statement audits: The case of the United States. Managerial Auditing Journal, 19(4), 544-555. http://dx.doi.org/10.1108/02686900410530547

\section{Copyrights}

Copyright for this article is retained by the author(s), with first publication rights granted to the journal.

This is an open-access article distributed under the terms and conditions of the Creative Commons Attribution license (http://creativecommons.org/licenses/by/3.0/). 